NBER WORKING PAPER SERIES

\title{
THE INTERNATIONAL LENDER OF LAST RESORT: HOW LARGE IS LARGE ENOUGH?
}

\author{
Olivier Jeanne \\ Charles Wyplosz \\ Working Paper 8381 \\ http://www.nber.org/papers/w8381
NATIONAL BUREAU OF ECONOMIC RESEARCH
1050 Massachusetts Avenue
Cambridge, MA 02138
July 2001

For helpful comments on the previous versions, we thank participants in the NBER Conference on Management of Currency Crises, and especially our discussant, Olivier Blanchard. We also thank Philippe Bacchetta, Patrick Bolton, Peter Clark, Daniel Cohen, Giovanni Dell'Ariccia, Enrica Detragiache, Piti Disyatat, Stanley Fischer, Gerhard Illing, Peter Isard, Christian Mulder, John Pattison, Pascal Rousseau, Alexander Swoboda, and participants at seminars at the Graduate Institute of International Studies, Humboldt University, the fifth annual meeting of the Latin American and Caribbean Economic Association, and the National Bank of Switzerland for helpful comments and discussions. This paper reflects the views of its authors, not necessarily those of the IMF. The views expressed herein are those of the authors and not necessarily those of the National Bureau of Economic Research.

(C) 2001 by Olivier Jeanne and Charles Wyplosz. All rights reserved. Short sections of text, not to exceed two paragraphs, may be quoted without explicit permission provided that full credit, including $(\subset$ notice, is given to the source. 
The International Lender of Last Resort:

How Large is Large Enough?

Olivier Jeanne and Charles Wyplosz

NBER Working Paper No. 8381

July 2001

JEL No. F32, F33, G21

\begin{abstract}
This paper considers how an international lender of last resort (LOLR) can prevent self-fulfilling banking and currency crises in emerging economies. We compare two different arrangements: one in which the international LOLR injects liquidity into international financial markets, and one in which its resources are used to back domestic banking safety nets. Both arrangements would require important changes in the global financial architecture: the first one would require a global central bank issuing an international currency, while the second one would have to be operated by an "international banking fund" closely involved in the supervision of domestic banking systems.
\end{abstract}

Olivier Jeanne

International Monetary Fund

Research Department

$70019^{\text {th }}$ Street N.W.

Washington, DC 20431

and CEPR

ojeanne@imf.org
Charles Wyplosz

Institut Universitaire des Hautes Etudes Internationales 11A, avenue de la Paix

1202 Geneve

and CEPR

wyplosz@hei.unige.ch 


\section{INTRODUCTION}

The Asian crises have triggered a debate on how new rules and institutions could increase the resilience of the international monetary system. Among many proposals, it has been suggested that an international lender of last resort would be a useful addition. One idea, a distant reminder of Keynes' proposal in Bretton Woods, is to set up an international central bank which would issue a global currency (Garten, 1998). Other ideas start from the observation that crisis lending by the international community has already evolved toward de facto lending in last resort since the Mexican bailout - a trend which, some argue, should be developed and institutionalized (Fischer, 1999). A report to the U.S. congress recently advocated the transformation of the International Monetary Fund into a "quasi-lender of last resort" lending at penalty rates and against good marketable collateral (IFIAC, 2000). Others have argued that the international lending-in-last-resort function should be undertaken by the Bank of International Settlements (Fratianni and Pattison, 2001).

The idea that an international lender of last resort (LOLR) could and should become the linchpin of the global financial architecture has been criticized on different grounds. It has been noted, first, that an international lender of last resort might worsen the moral hazard problem which, some argue, is one of the main causes of fragility of the international financial system (Calomiris, 1998). Another argument is that while a true international lender of last resort might be desirable in theory, it has no chance of being instituted in practice because the institutional changes involved go well beyond what the international community is ready to accept (Eichengreen, 1999). Some further claim that an international lender of last resort cannot function effectively unless it can issue an indefinite amount of its own currency (Capie, 1998), while others argue that the lender of last resort would need an amount of hard currencies which, though finite, is unrealistically large (Eichengreen, 1999; Rogoff, 1999).

The debate suggests that the notion of an international lender of last resort is not well understood, or at least subject to different interpretations. Questions range from the nature of crises to the arrangements required for the lender of last resort to operate. ${ }^{2}$ This paper proposes a formal framework which may help shed light on several of these issues.

The question with which this paper is primarily concerned is that of the size of the international LOLR. Does the international LOLR have to be a global central bank, or could it function effectively as a "fund" with limited and predetermined resources? And in the second case, how large should the fund be? To answer these questions, we build a model of an emerging economy that is vulnerable to international liquidity crises. An international lender of

\footnotetext{
${ }^{2}$ This lack of consensus reflects, to some extent, the state of the literature on the lending-in-lastresort doctrine. Indeed, the dominant genre in this literature seems to be the exegesis- the spirit and letter of Bagehot's Lombard Street being invoked to promote various interpretations of the "classical" doctrine. The more formal (model-based) literature, which is generally based on variants of the Diamond-Dybvig model, fails to capture many insights of its less formal counterpart. Naturally, the transposition of these debates to the international context makes things more difficult. See Freixas and Rochet (1997), chapter 7, or Bordo (1990) for reviews of the main debates on lending-in-last-resort.
} 
last resort can in principle cope with these crises by providing hard currency to cash-strapped countries. We scrutinize the size of LOLR interventions that are required to that effect.

This paper focuses on the effectiveness of an international LOLR in dealing with "twin" (banking and currency) crises. ${ }^{3}$ The need for an international LOLR stems, in our model, from a currency mismatch in the balance sheet of the emerging economy's banking sector. The domestic banking sector does not hold enough foreign currency assets to cover its short-term foreign currency liabilities. ${ }^{4}$ It is vulnerable, as a result, to panics in which short-term creditors withdraw their credit lines and depositors run on domestic banks. Like in some recent models of "twin" crises, these panics can be self-fulfilling because of the two-way feedbacks between the depreciation of the currency and the deterioration of banks' balance sheet (Burnside and others, 1999; Schneider and Tornell, 2000).

The question, then, is how large the international LOLR should be to remove the bad equilibrium. We find that the required size of the international LOLR crucially depends on how its resources are used. We compare two approaches, which correspond to the distinctionoriginally made by Goodfriend and King (1988) in a domestic contex - between "lending-inlast-resort as an input in monetary policy" and "lending-in-last-resort as an input in banking policy". In the former approach, the international LOLR injects its resources into the financial market, directly or through the domestic monetary authorities. In the second approach, the resources of the international LOLR are used to back domestic banking safety nets, such as discount-window lending policy by the central bank or a government guarantee of banks' foreign currency liabilities. The two approaches have the following implications for the size of the international LOLR.

- If the resources of the international LOLR are injected into the market, lending-in-lastresort has to be carried out by the issuer of the international currency (the U.S. Fed). The panic equilibrium is not removed by a limited fund, even a very large one.

- $\quad$ The lending-in-last-resort function can be effectively carried out by a limited fund if its resources are used to back domestic banking safety nets. Then the international LOLR resources do not need to be larger than the liquidity gap in the domestic banking sector, i.e., the difference between the domestic banking sector's short-term foreign currency liabilities and its foreign currency liquid assets.

\footnotetext{
${ }^{3}$ The role of the international LOLR in connection with sovereign liquidity crises is discussed by Sachs (1995), Jeanne (2000a), and Kumar and others (2000).

${ }^{4}$ If the assets and liabilities of domestic banks were denominated in the domestic currency, the domestic authorities would not need any external assistance to lend in last resort (Chang and Velasco, 2000; Goodhart and Huang, 2000). There would be no need for an international lender of last resort.
} 
Clearly, the second approach seems more practical than the first one. We argue, however, that it raises knotty agency problems that seem difficult to address under the current international financial architecture. In the second approach, the international LOLR would have to be an "International Banking Fund" closely integrated with the domestic systems of financial safety nets and supervision in emerging economies. It would have to assume a significant role in supervising domestic banking sectors. We do not see such an evolution as likely, at least in the foreseeable future. Nations remain jealous of their prerogatives in the regulation and supervision of their banking sectors and there seems to be little political appetite for a globally integrated system with the IMF, the BIS or any new institution at its center (Eichengreen, 1999; Giannini, 2000).

As a by product, our models yields interesting insights on monetary policy and exchange rate regimes in emerging economies. In particular, we find that the country's vulnerability to twin crises is the same under a flexible exchange rate regime than under a fixed peg. The reason is that the scope offered by exchange rate flexibility is largely illusory in a twin crisis. A floating exchange rate regime allows the domestic monetary authorities to set lower interest rates, but the associated exchange rate depreciation is no less destabilizing for the domestic financial sector - when there is a currency mismatch - than high interest rates. ${ }^{5}$ Indeed, if our analysis has any implications for exchange rate regimes, it is to suggest the optimality of very hard pegs, or dollarization. In our model, a credible commitment not to devalue the currency removes the bad equilibrium at no cost to the international community.

The paper is structured as follows. Section 2 presents some evidence on the Asian crises to motivate the model. Section 3 presents the model. Section 4 examines the role of domestic monetary policy, and section 5 that of an international lender of last resort. Section 6 concludes.

${ }^{5}$ A similar point is made by Bacchetta (2000) and Aghion and others (2000). See also Céspedes and others (2000), Christiano and others (2000) and Gertler and others (2000) for recent models of monetary policy with a balance sheet channel for the exchange rate. 


\section{The Asian Twin Crises: Some Stylized Facts}

Although the concomitance of banking and currency crises is not an original feature of the Asian 1997 crisis, ${ }^{6}$ it appeared as a very salient one for market participants at the time. Market analysts generally viewed the banking crises as the primary determinant of the currency instability, and conditioned their exchange rate forecasts on the prospects of a recovery in the banking sector. ${ }^{7}$ This section presents a few stylized facts on the banking and currency crises in the four countries most affected by banking instability: Indonesia, Korea, Malaysia, and Thailand. Our main purpose is to motivate the assumptions of the model presented in the following section.

\section{A. Maturity and Currency Mismatches}

The four crisis-hit countries received an exceptionally high level of capital inflows in the period leading up to the crisis. A significant fraction of these inflows took the form of shortterm credit in foreign currency. Meanwhile current account deficits were draining the foreign exchange reserves, leading to the buildup of a large and increasing gap between short-term external debt and the foreign exchange reserves at the central bank (figure 1). On the eve of the crisis, only Malaysia had enough reserves to cover its short-term debt to BIS-reporting banks. The international liquidity gap was especially large in Indonesia, where it exceeded 7 percent of GDP at the end of 1996 (table 1). A significant fraction of this build-up in short-term external debt reflected borrowing by domestic banks. The foreign liabilities of domestic banks increased markedly in all countries, most dramatically in Thailand, where they were approaching one third of GDP on the eve of the crisis (table 1).

Most of the external borrowing by banks and corporates was denominated in foreign currency, and the resulting currency risk was largely unhedged. Data limitations make it very difficult to assess the extent to which the currency risk was assumed directly by banks, or passed along to their borrowers. While bank regulation typically disallows currency mismatches, one of the lessons from the recent crises is that they do occur and can be sizeable. Even when the banks themselves avoid currency mismatches, firms which are their customers may carry such a risk on their own books. If many large firms fail simultaneously, so will their banks, especially as maturity transformation is a key function of the banking system.

\footnotetext{
${ }^{6}$ Kaminsky and Reinhart (1999) count 19 twin crises prior to 1995.

${ }^{7}$ See, for example, the Financial Time Currency Forecaster, 1997-98.
} 


\section{Figure 1. Reserves and Short-Term Debt}
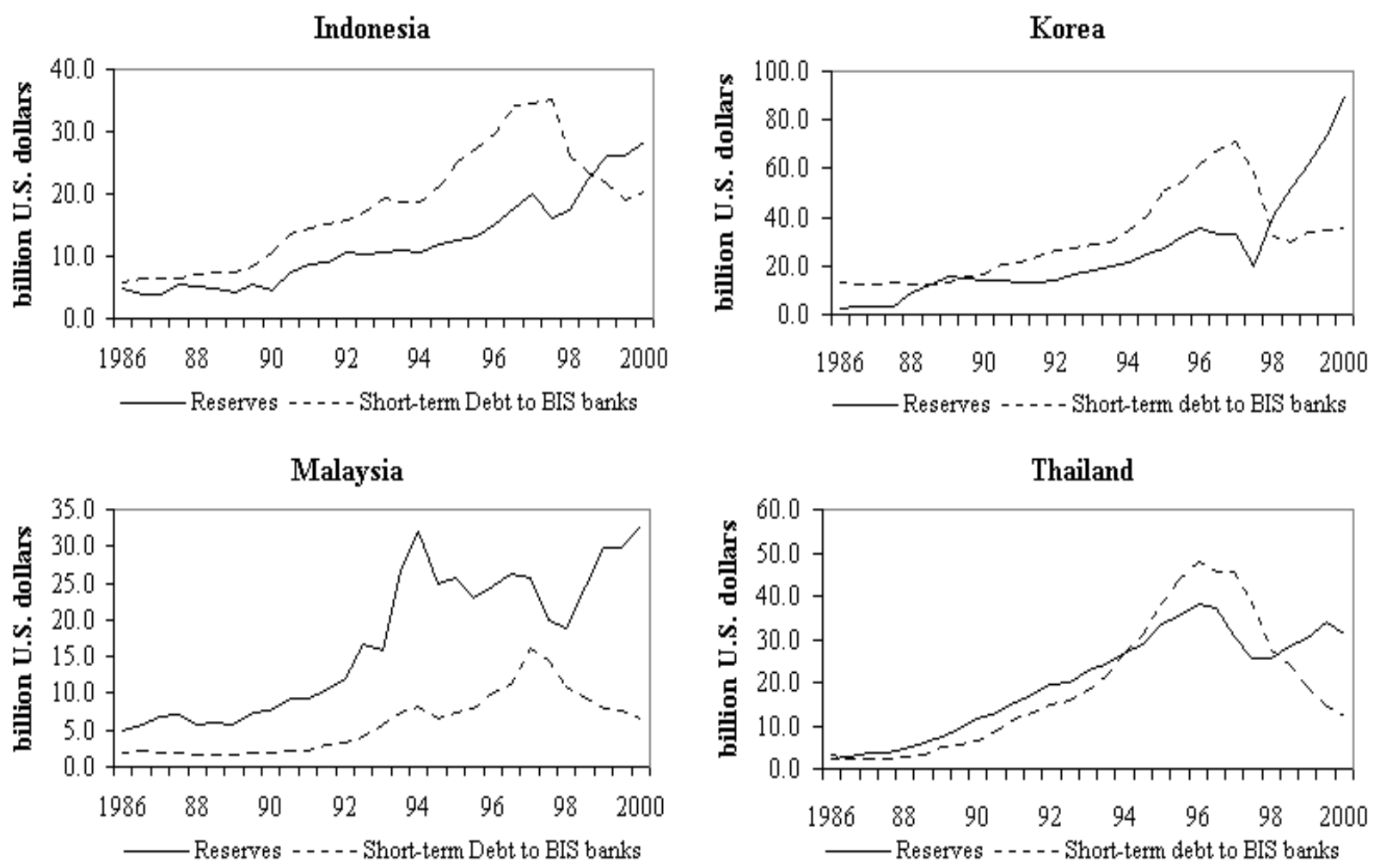


\section{Table 1}

The variables are expressed in percentage points of 1996 GDP, except when specified otherwise.

\begin{tabular}{|c|c|c|c|c|}
\hline & Indonesia & Korea & Malaysia & Thailand \\
\hline $\begin{array}{l}\text { Foreign exchange reserves } \\
\text { (end of 1996) }\end{array}$ & 7.8 & 6.4 & 26.0 & 20.5 \\
\hline $\begin{array}{l}\text { Short-term debt } \\
\text { to BIS-reporting banks } \\
\text { (end of 1996) }\end{array}$ & 15.0 & 12.0 & 11.2 & 25.1 \\
\hline $\begin{array}{l}\text { Foreign liabilities of } \\
\text { domestic banks } \\
\text { (end of 1996) }\end{array}$ & 5.6 & 8.7 & 11.2 & 27.1 \\
\hline $\begin{array}{l}\text { Peak-to-trough decline } \\
\text { in reserves }\end{array}$ & $\begin{array}{l}5.3 \\
(06.97-02.98)\end{array}$ & $\begin{array}{l}3.4 \\
(07.97-12.97)\end{array}$ & $\begin{array}{c}16.5 \\
(03.97-01.98)\end{array}$ & $\begin{array}{c}7.3 \\
(01.97-08.97)\end{array}$ \\
\hline $\begin{array}{l}\text { Decline in domestic banks' } \\
\text { foreign liabilities }\end{array}$ & $\begin{array}{c}-0.8 \\
(06.97-02.98)\end{array}$ & $\begin{array}{l}3.2 \\
(07.97-12.97)\end{array}$ & $\begin{array}{c}4.1 \\
(03.97-01.98)\end{array}$ & $\begin{array}{l}2.4 \\
(01.97-08.97)\end{array}$ \\
\hline $\begin{array}{l}\text { Liquidity support to } \\
\text { financial institutions } \\
\text { (June 1997-June 1999) }\end{array}$ & 31.9 & 6.9 & 13.8 & 22.5 \\
\hline $\begin{array}{l}\text { IMF-supported packages } \\
\text { (disbursement) }\end{array}$ & 8.8 & 6.0 & - & 7.9 \\
\hline $\begin{array}{l}\text { Bank closures } \\
\text { (percentage points of total } \\
\text { banking assets) }\end{array}$ & 18.0 & 15.0 & 0.0 & 13.0 \\
\hline \multicolumn{5}{|l|}{ Memorandum Items } \\
\hline $\begin{array}{l}\text { Total bank assets (1996) } \\
1996 \text { GDP (bn U.S. dollars) }\end{array}$ & $\begin{array}{r}90.0 \\
227.4\end{array}$ & $\begin{array}{l}300.0 \\
520.2\end{array}$ & $\begin{array}{l}300.0 \\
100.7\end{array}$ & $\begin{array}{l}190.0 \\
181.9\end{array}$ \\
\hline
\end{tabular}




\section{B. The Bust}

The crisis was accompanied by sharp depreciations of the exchange rate in all countries, a phenomenon that was more pronounced and persistent in Indonesia than elsewhere (figure 2). Indonesia was also exceptional in the level at which it raised its interest rate, a difference that reflected more the burst of inflation that followed the depreciation than an aggressive defense of the currency (figure 3). By contrast, the interest rates in Malaysia seem to have been somewhat insulated from exchange rate developments by capital controls.

Figure 2. Exchange Rates (1990-2000)

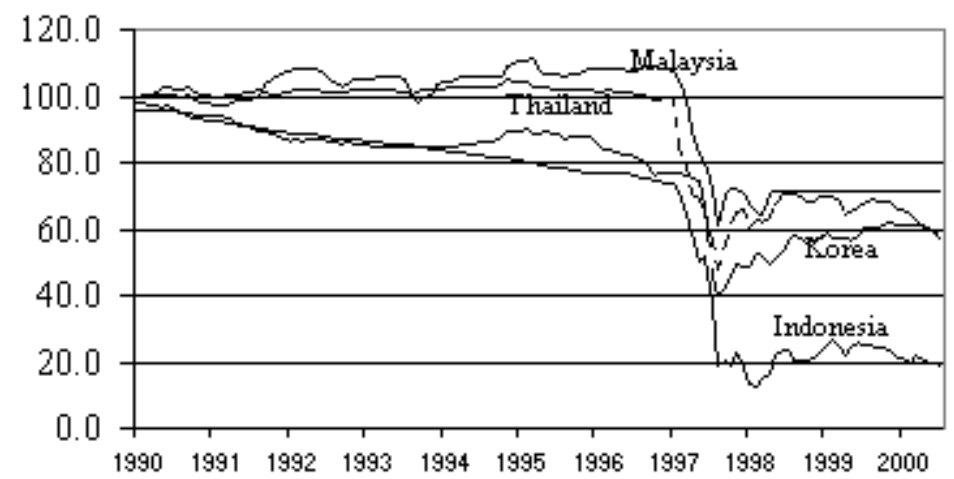

Figure 3. Money Market Interest Rates

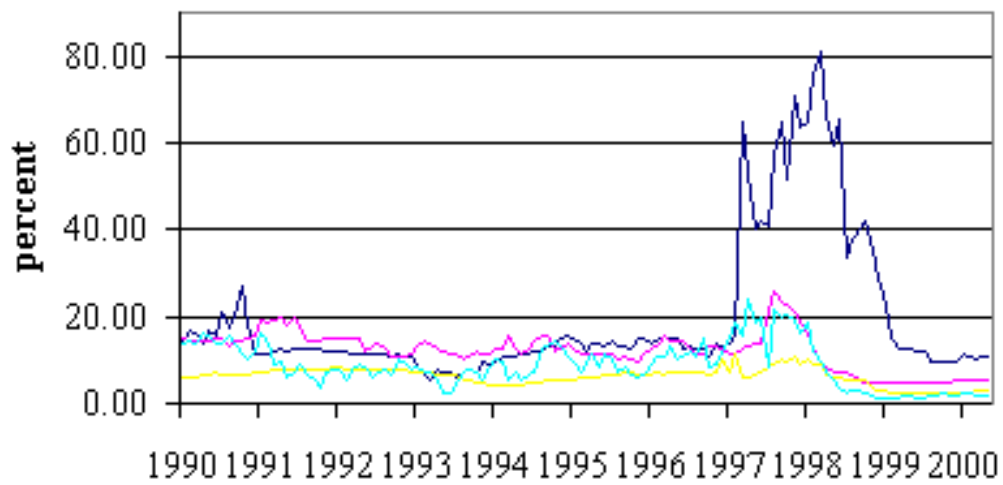

- INDONESIA - KOREA
MALAYSIA - THAILAND 
Simultaneously, the banking problems which had started to surface before the crisis took a sudden turn for the worse under the joint pressure of high interest rates, a depreciated currency, and a general loss of confidence. The currency depreciation had an adverse effect on the solvency of banks and firms because of the currency mismatches in their balance sheets. A large-scale run by domestic depositors was observed in Indonesia, where, by mid-December 1997, 154 banks representing half of the total assets of the system had faced a significant erosion of their deposit base (Lindgren and others, 1999). The other countries had to cope with a similar pressure coming from short-term creditors, especially foreign banks in Korea.

While the withdrawal of foreign credit lines certainly exercised a drain on the foreign exchange reserves, it does not seem to have been in general the primary cause of capital outflows. Table 1 reports peak-to-trough changes in foreign exchange reserves, as well as the change in the foreign liabilities of domestic banks at the time of the crisis. With the exception of Korea, the drop in reserves was much more driven by speculative capital outflows than by the repayment of banks' foreign debt. On average (excluding Korea), the fall in reserves was six times as large as the decline in banks' foreign liabilities. In other words, out of each dollar flowing out of these economies less than fourteen cents were used to repay the foreign liabilities of domestic banks. The rest was capital flight caused by domestic and foreign residents shifting their portfolio towards foreign assets and by speculation against the domestic currency.

The four countries suffered large falls in output - see figure 4-and there is evidence that the banking problems contributed to the slumps. The importance of banks in financial intermediation had increased markedly in the period leading up to the crisis. ${ }^{8}$ As the crisis developed, the most insolvent banks were closed, and the others saw their ability to lend curtailed by the withdrawal of short-term credit lines. Banking problems were associated with a severe decline in real credit (Lindgren and others, 1999). Although it is delicate, as always, to disentangle the respective contributions of demand and supply in the credit crunch, some studies have found evidence that it was in part supply-driven (Ghosh and Ghosh, 1999; Ding, Domaç, and Ferri, 1998).

\footnotetext{
${ }^{8}$ Total commercial bank and near-bank assets grew from between 50 and 100 percent of GDP in 1992 to between 150 and 200 percent of GDP at the end of 1996 (see table 1). As a comparison, deposit money banks held assets equal to 80 percent of GDP in the United States.
} 
Figure 4. Real GDP (1991=100)

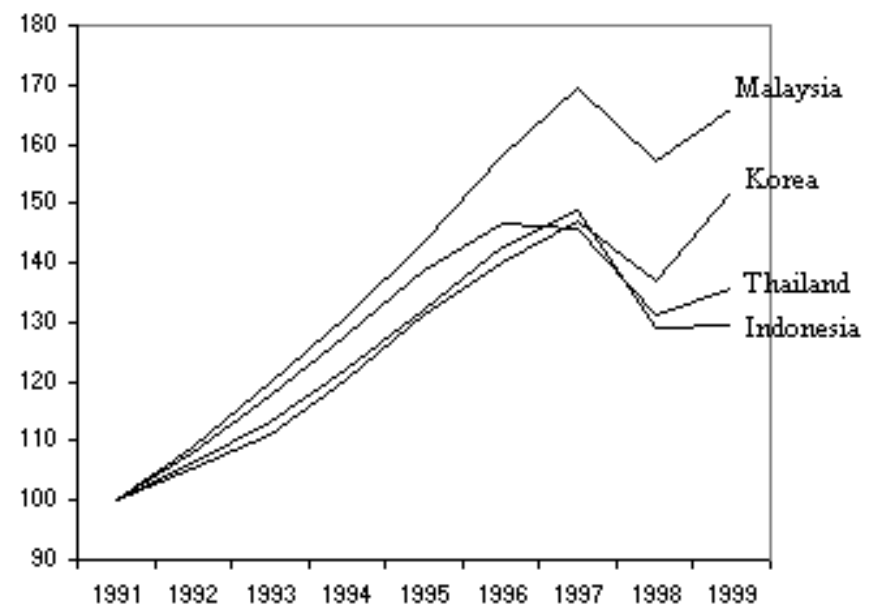

\section{Policy Responses}

Countries responded to the crisis on several fronts. We briefly review the emergency measures in macro and banking policies-leaving aside the more structural policies that were also initiated at the time of the crisis.

The first and most immediate decision in a currency crisis is the choice between increasing the interest rate in order to defend the currency, or let the exchange rate go. Our four countries did both to various extents, in part as the reflection of a dilemma in which the monetary authorities were caught. On the one hand, there were limits to which the interest rate could be raised, given the fragile state of the banking and corporate sectors. On the other hand, letting the currency depreciate had also adverse effects because of the currency mismatch in the balance sheets of banks and firms.

The limited scope offered by monetary policy led the authorities to rely on policies that were more directly targeted at banks. In all four countries central banks provided liquidity to financial institutions under various emergency lending and lender-of-last-resort facilities. The amounts were especially large in Indonesia and Thailand, where they exceeded 20 percent of GDP (table 1). This liquidity support was provided in domestic currency except in Korea, where it was primarily in U.S. dollars. To the extent that its impact on the monetary base was sterilized, however, the liquidity support provoked the same reserves losses irrespective of the currency in which it was provided. ${ }^{9}$

\footnotetext{
${ }^{9}$ Sterilization was largely effective in Korea and Thailand, but not in Indonesia and Malaysia.
} 
The provision of emergency liquidity was enhanced by various forms of government guarantees of banks' liabilities. None of the four countries had a formal insurance scheme on bank deposits at the beginning of the crisis, so that the guarantees had to be introduced under the pressure of events. As the severity of the crisis became apparent, and the introduction of more limited guarantees failed to restore confidence, the four countries ended up providing blanket guarantees for all depositors and most creditors (Lindgren and others, 1999). The guarantees did not always succeed in stemming capital outflows, however, possibly because of uncertainty about the government's ability to honor them. In Korea, for example, the guarantee on foreign debt was not sufficient to convince short-term foreign creditors to roll over their credit lines. This was followed by an effort to coordinate creditors, and resolved by voluntary debt restructuring. In all four countries, the guarantees were announced to be temporary and meant to maintain public confidence during the period of restructuring.

These policies were backed by large rescue packages arranged under the auspices of the IMF, with the notable exception of Malaysia. Interestingly, the size of these packages were of the same order of magnitude as - and in fact slightly larger than - the liquidity gap before the crisis (table 1). Malaysia instead chose to introduce drastic capital controls.

\section{MODEL}

One feature of twin crises that the Asian experience illustrates very well is the mutually self-reinforcing nature of banking and currency fragilities. As Kaminsky and Reinhart (1999) put it: "Financial-sector problems undermine the currency. Devaluations, in turn, aggravate the existing banking-sector problems and create new ones. These adverse feedback mechanisms...can be amplified, as we have seen in several of the recent Asian crises, by banks' inadequate hedging of foreign-exchange risk."

We present a model in which these negative feedback effects are linked together in the following vicious spiral:

\section{Figure 5. The Vicious Spiral}

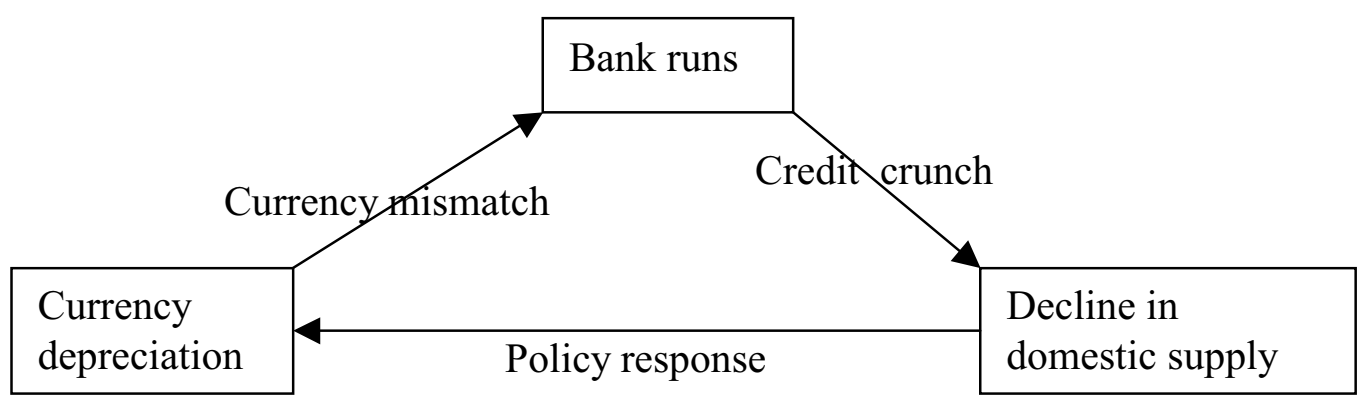


The currency depreciation triggers bank runs because of a currency mismatch in the balance sheets of domestic banks. Banking problems in turn depress domestic supply by inducing a credit crunch. Finally, the decline in domestic supply weakens the currency, as the domestic authorities attempt to boost output by a depreciation. This closes the circle.

In our model this vicious circle goes beyond making twin crises simply persistent or difficult to manage: it makes them self-fulfilling. We would like to emphasize, however, that we do not view this paper as a contribution to the debate on whether twin crises are self-fulfilling in the real world. The purpose of this paper is not to convince the reader that they were, in Asia or elsewhere. It is to study the feasibility of an international LOLR. It makes sense to look at this question in the context of a model with self-fulfilling bank runs, which is the problem that a LOLR is supposed to solve in theory.

\section{A. The Linkage from the Currency Depreciation to Bank Runs}

We consider a two-periods model of an open emerging economy $(t=1,2)$. The agents are: the domestic private banks, their depositors, and the domestic central bank. For the sake of brevity and couleur locale we call the domestic and foreign currencies "peso" and "dollar" respectively. We denote by $S_{t}$ the price of one peso in terms of dollars at time $t$. An increase in $S_{t}$ thus corresponds to an appreciation of the peso.

The peso/dollar exchange rate satisfies uncovered interest parity (UIP):

$$
S_{1}=\frac{1+i}{1+i^{*}} S_{2}^{e}
$$

where $S_{2}^{e}$ is the expected exchange rate, and $i$ and $i^{*}$ are respectively the peso and dollar riskless interest rates in period 1.

Domestic banks have deposits and income streams denominated in dollar and peso. The currency composition of banks' assets and liabilities is inherited from an earlier time, in which some banks found it optimal to borrow or lend in dollar, or for some reason could not borrow in peso. ${ }^{10}$ It does not seriously weaken our analysis to take the structure of banks' balance sheets as given, since we focus here on the policy measures at the time of the crisis, after the currency

${ }^{10}$ Chang and Velasco (2000) and Goldfajn and Valdes (1999) endogenize the maturity mismatch in open economy versions of the Diamond-Dybvig model of bank runs. Burnside and others (1999) and Schneider and Tornell (2000) endogenize the currency mismatch as the result of a government guarantee on foreign currency liabilities, while in Caballero and Krishnamurty (2000) it is the result of domestic financial underdevelopment. 
and maturity mismatches have built up. ${ }^{11}$ We denote by $D(j)$ and $D^{*}(j)$ the quantities of peso and dollar deposits at bank $j$, and by $R_{t}(j)$ and $R_{t}^{*}(j)$ its peso-denominated and dollardenominated income streams in period $t$.

Deposits are repayable on demand, and demand is served sequentially, like in Diamond and Dybvig's (1983) model of bank runs. Each bank has a continuum of atomistic depositors who decide at $t=l$ whether or not to withdraw their deposits. The withdrawing depositors are randomly allocated in a queue which determines the order in which they are served. The bank repays depositors by selling its assets for peso or dollars in the market. If the bank does not have enough assets to repay all the withdrawing depositors in period 1, the depositors at the end of the queue, and those who have not joined the queue, receive nothing. In the opposite case, the assets that remain in the possession of the bank at the end of period 1 are sold in period 2 to repay the remaining depositors - those who have not withdrawn in period 1. Deposits are interest-bearing, and yield the riskless interest rate corresponding to their currency of denomination. The holder of one dollar (peso) of deposit at time 1 is entitled to withdraw $1+i^{*}$ $(1+i)$ dollar (peso) at time 2 .

We assume that bank assets are liquid in the sense that they can be sold costlessly on a perfectly competitive market at their present discounted value. This assumption is important insofar as it rules out bank runs a la Diamond-Dybvig, which are caused by the illiquidity of bank assets. ${ }^{12}$ Bank $j$ is solvent if, and only if, the present value of its income streams exceeds the value of its deposits, that is:

$$
D^{*}(j)+S_{1} D(j) \leq R_{1}^{*}(j)+\frac{R_{2}^{*}(j)}{1+i^{*}}+S_{1}\left(R_{1}(j)+\frac{R_{2}(j)}{1+i}\right)
$$

If this solvency condition is satisfied the bank can repay all its depositors irrespective of the date at which they withdraw, and depositors have no (strict) incentives to withdraw early. If this condition is not satisfied, then all depositors run on the bank at period 1. Some depositors

${ }^{11}$ Of course it would be essential to endogenize the currency mismatch if we wanted to understand how policy measures can prevent its emergence ex ante (Jeanne, 2000b).

${ }^{12}$ In theory, the benefit of banking intermediation should be linked to the illiquidity of bank assets. Assuming that bank assets are sold at a discount relative to their present value would not change the thrust of our results, and it is interesting to see that in fact we do not need this assumption. The role played by the illiquidity assumption in the bank run literature is played here by a state-conditional depreciation of the domestic currency. 
will have to take a loss, and each depositor minimizes the likelihood of being one of them by withdrawing his deposits early. Note that by contrast with the Diamond-Dybvig model the equilibrium is unique at the level of an individual bank. For a given balance sheet structure, the occurrence of a run is determined by interest and exchange rates, variables that are exogenous to the actions of the bank's depositors (the bank being very small).

In order to simplify the exposition we shall consider an extreme case of currency and maturity mismatch: all the deposits are denominated in dollar and banks receive only one income stream, which is denominated in peso and arrives in period 2. In terms of the variables of our model this corresponds to the case where $R_{1}^{*}, R_{2}^{*}, R_{1}$ and $D$ are equal to zero. The assumption that $R_{1}^{*}$ and $R_{2}^{*}$ are equal to zero does not restrict the generality of the analysis, and is made simply to alleviate the algebra. The case where $R_{1}$ and $D$ are different from zero is analyzed in the appendix. It has interesting implications for domestic monetary policy, which we choose not to discuss here because they are not essential to the core of our argument.

Using the interest parity condition (1) to substitute $S_{1}$ and $i$ out of the solvency condition (2), we find that bank $j$ is solvent if and only if:

$$
D^{*}(j) \leq \frac{S_{2}^{e}}{1+i^{*}} R_{2}(j)
$$

In order to avoid the discontinuity associated with the use of integers we assume that the set of banks is isomorphic to a continuum of mass 1, and that the banks' characteristics are continuously distributed. As condition (3) makes clear, the set of solvent banks shrinks if the expected peso exchange rate depreciates ( $S_{2}^{e}$ goes down). Consequently the number of bank runs in period $1, n$, is a continuous and decreasing function of the expected exchange rate:

$$
n=N\left(S_{2}^{e}\right), \quad N^{\prime}<0 .
$$

An expected depreciation of the peso reduces the value of bank assets relative to their liabilities, drawing a larger number of banks into insolvency.

\section{B. The Reverse Linkage}

The linkage from bank runs to exchange rate expectations in the spirit of the escape clause or "second-generation" approach to currency crises (Jeanne, 2000c). It involves the endogenous policy response of the domestic authorities to the disruption in real activity induced by the bank runs. 
We assume that period 2 output is given by a standard Phillips Curve augmented by a term reflecting the real disruption induced by runs on domestic banks in period 1. The Law of One Price applies, so that the Phillips Curve can be written in terms of the exchange rate:

$$
Y_{2}=\bar{Y}-\alpha\left(S_{2}-S_{2}^{e}\right)-f(n), \quad f(0)=0, \quad f^{\prime}>0
$$

$\bar{Y}$ is the natural level of output and $n$ is the number of banks that are subject to runs in period 1 . Bank runs reduce output by inducing a credit crunch: the banks that are subject to runs are no longer able to provide loans to borrowers with no easy access to other forms of finance. ${ }^{13}$ Function $f(\cdot)$ characterizes how the output loss in period 2 depends on the number of bank runs in period 1 . The output loss is increasing with the number of runs, presumably in a nonlinear way: for example, one could assume that a small number of bank runs has no effect on output but that widespread runs (the truly systemic banking crises) entail large output losses.

The domestic government minimizes the quadratic loss $L_{2}=\left(Y_{2}-\bar{Y}\right)^{2}+\beta\left(S_{2}-\bar{S}\right)^{2}$. Like in the classical Barro-Gordon setting, the exchange rate term captures an aversion to changes in the domestic price level (which are equivalent to changes in the exchange rate under the Law of One Price). We assume that the domestic government behaves in a discretionary way, that is, minimizes its loss function in period 2 taking period 1 expectations as given. Using (5) to substitute out $Y_{2}$ in $L_{2}$, and minimizing over $S_{2}$, one finds that the period 2 exchange rate is a function of the number of bank runs and of the expected exchange rate:

$$
S_{2}=\frac{1}{\alpha^{2}+\beta}\left(\beta \bar{S}+\alpha^{2} S_{2}^{e}-\alpha f(n)\right)
$$

The expected exchange rate in period 2 is decreasing with the number of bank runs in period 1, as the authorities attempt to mitigate the effect of the credit crunch on domestic output by a depreciation of the domestic currency.

\section{Multiple Equilibria}

We look at rational expectations Nash equilibria, in which each depositor decides whether or not to withdraw in period 1, taking the actions of the other depositors as given. Under rational expectations, the expected exchange rate and its realized level must coincide,

${ }^{13}$ Disyatat (2000) presents a model of an open economy in which a depreciation tends to stimulate output because of a short-run Phillips curve, but reduces the domestic banks' ability to lend. The credit crunch in his model comes from a reduction in banks' net worth, not from runs. 
since there is no uncertainty in the model. Replacing $S_{2}^{e}$ by $S_{2}$ in equations (4) and (6), we find that the number of bank runs and the second period exchange rate are linked by two relationships:

$$
\left\{\begin{array}{l}
n=N\left(S_{2}\right), \\
S_{2}=\bar{S}-\frac{\alpha}{\beta} f(n),
\end{array}\right.
$$

The Currency-Mismatch (CM) relationship characterizes the linkage from the exchange rate to the number of bank runs. Its shape is determined by the currency mismatch in banks' balances sheets - in the absence of mismatch the number of bank runs would not depend on the exchange rate. The Credit-Crunch (CC) relationship characterizes the linkage from bank runs to the exchange rate. This link arises because the domestic authorities depreciate the currency in response to a credit crunch.

Figure 6 shows the $(\mathrm{CC})$ and $(\mathrm{CM})$ curves with the number of bank runs on the $x$-axis and the exchange rate on the $y$-axis. Both curves are downward-sloping, so that the model generically gives rise to multiple equilibria. In the case represented in figure 6 there are two stable equilibria, corresponding to points A and C. In the good equilibrium (point A ) the currency is strong and only the "truly insolvent" banks are subject to runs. In the bad equilibrium (point $\mathrm{C}$ ) the currency is expected to depreciate markedly and all the banks are subject to runs. The equilibrium corresponding to point $\mathrm{B}$ is unstable. ${ }^{14}$

Figure 6. Twin Crisis Equilibria

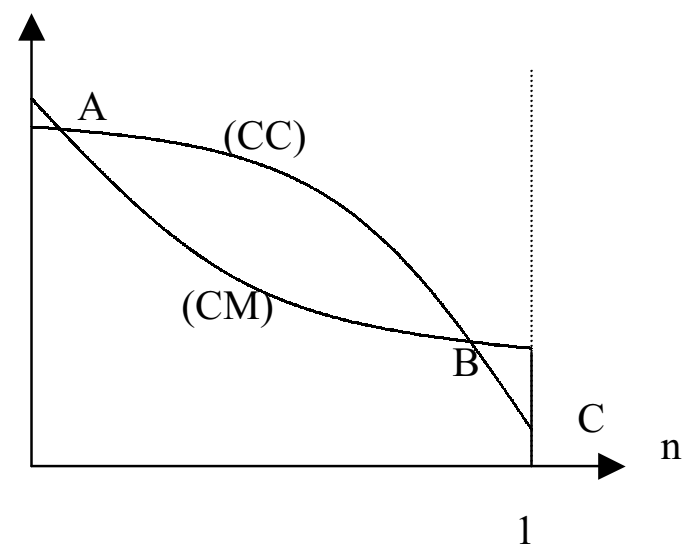

${ }^{14}$ At point $\mathrm{B}$, the bank runs caused by a slight fall in the expected exchange rate tend to depreciate the exchange rate even further, pushing the economy to point $\mathrm{C}$. 
Note that although bank runs may be self-fulfilling in this model, they never hit an "illiquid but solvent" bank. There is a perfect coincidence, in equilibrium, between runs and insolvency. In the bad equilibrium, the banks that are subject to runs are made insolvent by the pressure on the exchange rate. Some of these banks are "truly" or "virtually" solvent, in the sense that they would be solvent in the good equilibrium. But it is important to keep in mind that "true solvency," understood in this sense, is an out-of-equilibrium concept.

\section{How Panics Depend on the Fundamentals}

The model makes several predictions about the conditions under which twin crises occur. First, there must be a significant currency mismatch in the balance sheets of domestic banks - the equilibrium is uniquely determined if banks' assets and liabilities are denominated in the same currency and, by continuity, if the two are sufficiently close. Second, the weight of the exchange rate (or price) objective in the authorities' loss function must be sufficiently small. If this weight, $\beta$, is large, the bad equilibrium disappears because bank runs are no longer expected to significantly depreciate the currency. ${ }^{15}$ Finally, self-fulfilling twin crises are more likely when the foreign interest rate, $i^{*}$, is high, because this increases the number of insolvent banks, other things equal. ${ }^{16}$

It is not difficult to complicate slightly the model so as to make the multiplicity of equilibria contingent on other economic variables. For example, we could introduce a persistence effect in the Phillips curve, replacing (5) by:

$$
Y_{2}=\bar{Y}+\rho\left(Y_{1}-\bar{Y}\right)-\alpha\left(S_{2}-S_{2}^{e}\right)-f(n)
$$

The second period output now depends on its first period level. Consequently, the second period exchange rate will also depend on the first-period output $Y_{1}$, and twin crises can occur only if $Y_{1}$ is not too high. These results are broadly consistent with Kaminsky and Reinhart's (1999) observation that twin crises are preceded by recessions or below normal economic growth, and tend to occur when U.S. interest rates are high. The contingency of the multiplicity on output is not essential for our discussion, however, and we use the simpler model.

${ }^{15}$ In the limit case where $\beta$ is infinite, the $(C C)$ curve in figure 6 is horizontal so that there is one unique equilibrium.

${ }^{16}$ Raising $i *$ increases the number of insolvent banks for a given exchange rate and shifts the locus $(C M)$ to the right. Thus this could shift the economy from a state where the $(C M)$ is everywhere below $(C C)$ - so that there is one unique equilibrium with no bank run - to a state where $(C M)$ and $(C C)$ have multiple intersections. 
Whether the economy lands on one or the other of the equilibrium may depend on a sunspot variable, which may or not be correlated with the underlying fundamentals. As one of us has argued elsewhere, the sunspot should not be interpreted literally, but rather as a "black box" for the little understood phenomena involved in the selection of the equilibrium in the real world (Jeanne, 2000c). ${ }^{17}$ We do not loose much from using this black box in this paper, since we look at policy measures that aim at removing the multiplicity of equilibria - not measures aimed at favoring the selection of the good equilibrium.

\section{The Limits of Monetary Policy}

This section presents the implications of the model for domestic monetary policy. We show that domestic monetary policy does not offer the right tools for dealing with twin crises. This point, which is of independent interest, is also important to justify the intervention of an international LOLR. If the domestic authorities could deal with twin crises using monetary policy there would be no need for an international LOLR. In addition, the model has interesting implications for exchange rate regimes, which we briefly discuss in section 4.2.

\section{A. The Irrelevance of Interest Rates}

The most immediate question that policymakers have to solve in the heat of crises is macroeconomic: what to do with the interest rate? The debates spurred by the IMF's policy recommendations in the Asian crisis have seen the opposition between two views: the view that the interest rate should be raised, at least for a while, in order to defend the currency, and the view that it should be kept at a low level to spare the domestic economy. The advocates of the latter view have pointed out that a policy of high interest rate may be self-destructive to the extent that it aggravates the real problems in the economy, in particular in the banking sector (Furman and Stiglitz, 1998). The opposite side has emphasized that letting the currency depreciate is not a viable alternative when there is a currency mismatch in the balance sheet of banks or firms. Our model is consistent with at least one part of each view: monetary policy simply does not offer the right tools to deal with twin crises.

In our model, low or high interest rates are equally ineffective against twin crises. In order to establish this point it is sufficient to recall that the domestic interest rate, $i$, was not in the list of variables that determine the set of equilibria. Hence if the economy is vulnerable to a self-fulfilling twin crisis, there is nothing that the domestic authorities can do about it by manipulating the domestic interest rate.

\footnotetext{
${ }^{17}$ Morris and Shin (1998) present a possible theory for the selection of the equilibrium. Their approach requires the number of equilibria to depend on the value of some exogenous hidden fundamental about which market participants receive private signals. It could be applied to our model by assuming, for example, that market participants do not know the true value of the domestic government's aversion to inflation, $\beta$.
} 
One may dig out the economic intuition behind this result by going back to the condition for bank solvency, equation (3). The solvency of banks is determined by one variable: the time 1 dollar price of time 2 pesos, $S_{2}^{e} /\left(1+i^{*}\right)$. Under UIP, his price can be decomposed as the product of two terms, the time 1 peso price of a time 2 peso, and the time 1 exchange rate:

$$
P^{*}=\frac{1}{1+i} \quad \frac{(1+i) S_{2}^{e}}{1+i^{*}}
$$

The first term is decreasing with $i$, while the second term is increasing with $i$. Increasing $i$, thus, has two opposite effects, which capture the two sides of the debate mentioned above. On the one hand, raising $i$ undermines banks' solvency by depressing the peso price of long-term peso assets. On the other hand, this enhances banks' solvency by appreciating the domestic currency. The first effect arises because of the maturity mismatch in the balance sheet of banks, and the second effect because of the currency mismatch. On balance the two effects cancel each other out, so that the level of the interest rate is irrelevant.

The two effects exactly cancel each other out because of the particular assumptions we have made on the currency and maturity structure of banks' balance sheets - that bank deposits are denominated in dollars, and that their receipts are given in period 2 pesos. The robustness of our results to more general assumptions is explored in the appendix. We show there that the solvency of banks is no longer independent of the level of the interest rate, so that a policy of high interest rates may or not dominate a policy of low interest rates. A policy of high interest rates tends to become more desirable when the maturity mismatch between the pesodenominated assets and liabilities of banks is less pronounced.

This extension, however, does not invalidate our main conclusion. If the weight of price stability in domestic objectives is too low and the currency mismatch is severe, self-fulfilling twin crises may exist, and if they do monetary policy is powerless in preventing them. This is because the scope of monetary policy in preserving banks' solvency, although no longer completely empty, remains limited, and contingent on exchange rate expectations.

\section{B. Implications for Exchange Rate Regimes}

The recent major twin crises were all associated with fixed but adjustable currency pegs, whence the natural conclusion that in order to be viable, exchange rate regimes have to be either more flexible or more fixed. The exchange rate alternative, for emerging economies, is increasingly defined as a choice between corner solutions - between exchange rate flexibility and very hard pegs (Eichengreen, 1999; Rubin, 1999).

In the debate between the extremes, a classical argument in favor of flexibility is that it gives monetary policy more scope to respond to shocks, especially in times of crisis. However, the apparent margin of maneuver offered by a flexible exchange rate is largely illusory in our 
model. ${ }^{18}$ The reason is that the threat is not a currency crisis (a run on the central bank's foreign exchange reserves) but a bank crisis (a run on dollar deposits in banks). The occurrence of bank runs is determined by the dollar price of future pesos. Whether a given change in this price is achieved by changing the interest rate or the exchange rate is irrelevant for financial stability. While it is true that a floating regime allows the monetary authorities to set a lower interest rate in the face of speculative pressure, the resulting depreciation hurts domestic banks no less than high interest rates.

Indeed, if the model has an implication for exchange rate regimes, it is rather to suggest the optimality of very hard pegs, or dollarization. If the defense of the fixed peg is delegated to a conservative central banker putting a very high weight $\beta$ on exchange rate stability, the bad equilibrium disappears. If, more generally, the domestic authorities find a way to make a credible commitment to exchange rate stability, the vicious spiral that underpins twin crises is broken, because bank runs no longer feed devaluation expectations. Dollarization can be interpreted as the limit case where $\beta$ is infinite, so that there is no exchange rate uncertainty. Twin crises obviously cannot arise in countries that have dollarized, since then there is no currency mismatch in the balance sheets of banks - both banks' assets and liabilities are denominated in dollars.

This might lead us to conclude in favor of very hard pegs over exchange rate flexibility. But this conclusion should be qualified by two important caveats. First, the currency mismatch that is taken as exogenous in the model could in fact be endogenous to the exchange rate regime. It is often argued that regimes with fixed but adjustable exchanges are conducive to currency mismatches because domestic borrowers tend to underestimate the risk of a devaluation (Lindgren and others, 1999), or feel protected by an implicit guarantee of their foreign currency liabilities if they are made insolvent by a devaluation (Calomiris, 1998; Burnside, Eichenbaum and Rebelo, 1999). The model does not capture one possible benefit of exchange rate flexibility — in fact, the only possible benefit, under our assumptions — which is that it prevents the emergence of currency mismatches.

The second caveat is that while hard pegs or dollarization remove the twin crises resulting from currency mismatches in the banking sector - the crises that we focus on in this paper-they do not remove banking panics a la Diamond-Dybvig, which result instead from the illiquidity of bank assets. If bank runs a la Diamond-Dybvig are possible, a group of countries linked by a system of hard pegs or a common currency may still need an international lendingof-last-resort arrangement. This is why the reluctance of the U.S. Fed to assume the role of lender of last resort abroad may be viewed as a valid argument against dollarization in Latin

\footnotetext{
${ }^{18}$ It is completely illusory under the assumption that $D$ and $R_{1}$ are equal to zero. It is not completely illusory, but remains limited, in the more general case (see appendix).
} 
American countries. This is also why the euro area may need an international lender of last resort. $^{19}$

\section{THE INTERNATIONAL LOLR}

Our model seems to provide an ideal setting for the intervention of international LOLR. Domestic banks are vulnerable to self-fulfilling runs because the country as a whole lacks international liquidity. Perhaps the bad equilibrium could be removed by an international LOLR standing ready to provide the missing international liquidity to the country in the event of a twin crisis. $^{20}$

Let us rephrase the question in the context of the model, with some new notations. Let $D^{*}=\int D^{*}(j) d j$ be the aggregate level of dollar deposits in the domestic banking sector, $X^{*}$ the level of foreign exchange reserves at the domestic central bank, and $L^{*}$ the dollar endowment of the international LOLR. The international LOLR could promise to augment the domestic foreign exchange reserves by lending up to $L^{*}$, in which case the domestic central bank's access to international liquidity is limited to $X^{*}+L^{*}$ in a crisis. Alternatively, the international LOLR could use its resources directly, without the mediation of the domestic authorities. The question, in both cases, is how large $L^{*}$ should be to remove the bad equilibrium.

Throughout the analysis we require the international LOLR to remove the bad equilibrium without rescuing the insolvent banks in the good equilibrium. In the good equilibrium some banks - the "truly insolvent" ones - are subject to runs (see Figure 6). Rescuing these banks, however, is a bail-out, not a lending-in-last-resort operation. Bailing out insolvent banks has costs in terms of moral hazard ex ante which, although they are not explicitly modeled in our framework, may be important in the real world. As a matter of definition, it is not the purpose of a lender of last resort to bail out truly insolvent institutions.

${ }^{19}$ See Prati and Schinasi (2000) for a discussion on lending-in-last-resort arrangements in the euro area.

${ }^{20}$ The lending-in-last-resort arrangement could involve a pool of private banks. However, there are reasons (outside of the model) why the provision of liquidity by public institutions may be more effective. In particular, it may be difficult for private banks to commit not to hedge their risk by market operations that drain international liquidity from the country in the event of a crisis. A comparison between the various possible types of lending-in-last-resort arrangement is outside the scope of this paper. 


\section{A. A Global Central Bank}

Goodfriend and King (1988) argue, in a domestic context, that the lender of last resort should inject liquidity into the market, by open market operations. ${ }^{21}$ Lending-in-last-resort, in other words, should involve the same operations as monetary policy in normal times-although possibly to a much larger scale. According to this view, lending-in-last-resort policies in which the authorities attempt to by-pass the market and target liquidity directly at selected institutions - for example by lending to them at the discount window - is a vestige of a time when financial markets did not have the depth and efficiency that they have achieved today.

This view is based on the premise that market forces will allocate the liquidity better than the authorities. Market participants have more information than the authorities on the situations of individual banks, and are not subject to the temptation of bailing out insolvent banks under political pressure. Market forces, thus, will ensure that the liquidity is allocated to the "truly solvent" banks. Goodfriend and King call this policy "lending-in-last resort as an input into monetary policy", as opposed to "lending-in-last resort as an input into banking policy".

What should the international LOLR's do, according to this approach? In the closedeconomy context, considered by Goodfriend and King, the lender of last resort injects liquidity into the market by open market operations, that is by buying domestic bonds in exchange of domestic money. The open-economy analog is an injection of international liquidity, that is, in our model, dollars. The international LOLR provides international liquidity to the market by buying peso-denominated bonds in exchange of dollars, that is, by a sterilized foreign exchange intervention. If markets are perfectly integrated internationally, it does not matter whether the foreign exchange intervention is realized by the international LOLR or by the domestic central bank, or in which point of the globe the intervention is implemented.

In our model, this approach is completely ineffective in removing the bad equilibrium. Because of UIP, sterilized foreign exchange interventions have no impact on the interest rate, the exchange rate or the depositors' actions. In particular, every billion dollars that is injected in the market by the domestic central bank simply goes out of the country in capital outflows. Domestic foreign exchange interventions, in other words, are immediately sucked out of the country in capital outflows, instead of going to the agents that need foreign liquidity the most, the domestic banks that are subject to runs.

Our model suggests that if lending-in-last resort is an input into monetary policy, then it should be carried out by the center's monetary authorities (in the present case where foreign assets are dollar-denominated, the U.S. Fed). There are at least two ways in which this statement can be understood. First, as we already saw, lowering the foreign interest rate, $i^{*}$,

${ }^{21}$ The origin of this view is sometimes traced back to Thornton ([1802] 1978) and Humphrey (1975) - see Fischer (2000). 
may remove the bad equilibrium. Second, the Fed could successfully peg the dollar price of future pesos at the good equilibrium level, $P_{A}^{*}$. If the dollar price of peso bonds is equal to $P_{A}^{*}$, the number of banks runs is equal to its good equilibrium level, $n_{A}$, so that the set of equilibria is reduced to the good equilibrium.

It is important to see that in our model, the Fed can successfully peg the dollar price of future pesos using sterilized foreign exchange interventions because it can create an indefinite quantity of dollars. Recall that under UIP, the dollar price of one future peso is given by:

$$
P^{*}=\frac{S_{2}^{e}}{1+i^{*}}
$$

In our model, the demand for dollars is infinite if the Fed attempts to peg $P^{*}$ at a level that is higher than that implied by the equation above. Foreign exchange speculators would want to borrow an infinite quantity of pesos and exchange them for dollars. In practice, however, there are limits to the short positions that speculators can take in the foreign exchange market. The Fed could inject dollars in the market until the point where market participants can no longer increase their short positions in peso (because of credit constraints or for other reasons) so that uncovered interest parity ceases to apply. However, the demand for dollars would remain extremely large: the operation would require an immense liquidity injection at the global scale, which can be implemented, in practice, only by the issuer of the center currency. Making international lending-in-last-resort an input in monetary policy thus vindicates Capie's (1998) claim that the international lender of last resort must be the issuer of the international currency - a global central bank, or the U.S. Fed if the international currency is the dollar.

These results stem, in part, from our assumption that UIP applies — as long as speculators' borrowing ability is not exhausted — and that financial markets are perfectly integrated internationally. In the presence of portfolio effects, the domestic currency could in principle be strengthened by sterilized foreign exchange interventions. If financial markets were segmented, international liquidity might have a better chance to reach domestic banks if it were injected in the domestic financial market (the authorities would then have to exhaust the borrowing ability of domestic speculation, rather than global speculation).

Market segmentation is to some extent a policy variable: the domestic authorities can enhance the segmentation of financial markets by introducing capital controls. While the analysis of capital controls is outside the scope of this paper, it would be interesting to study whether, and how, capital controls can remove self-fulfilling twin crises in our model. While capital controls may prevent depositors from taking their dollar deposits out of the country, they will not prevent them from running on the domestic banks that they view as insolvent. The solvency of banks in turn results from the expected exchange rate. Hence capital controls can remove twin crises only to the extent it gives the authorities more scope in influencing exchange rate expectations. This could be the case, for example, if the controls introduce a wedge in the interest parity condition. 
Let us conclude this section with a metaphor - an hydraulic one, as is often the case in monetary economics. Imagine a small harbor in Brittany: the tide is low and boats are resting on the bottom of the sea, inside the harbor. Lending-in-last-resort by injecting liquidity into the market is like trying to lift the boats by pouring water into the ocean. To be successful, this approach requires an immense reserve of water (an ability to melt the North Pole, say). Imagine now that the harbor is separated from the ocean by a wall and a door. Once the door is closed (capital controls are introduced), one obviously needs to pour much less liquidity inside the harbor to lift the boats.

\section{B. An "International Banking Fund"}

We now consider some arrangements in which the international LOLR can operate as a limited fund. The main difference with the previous section is that the resources of the international LOLR are channeled to the banks on a case-by-case basis instead of being simply "thrown at the market"-in Goodfriend and King's terminology, the international LOLR provides an input into banking policy, instead of monetary policy. We consider below two arrangements. In the first one, the resources of the international LOLR are used to finance discount-window lending by the domestic central bank. In the second one, the international LOLR backs limited guarantees on dollar deposits at domestic banks.

In the discount-window lending policy, the domestic banks that are subject to runs queue at the discount window of the domestic central bank. ${ }^{22}$ The latter selects the "truly solvent" banks, and lends them all the dollars they need to repay their depositors. The remaining banks receive nothing and collapse. It is important to keep in mind that the solvency of banks is contingent on the equilibrium, and that we define "true solvency" with reference to the good equilibrium. In other terms, in the bad equilibrium the authorities assess the solvency of banks as if the economy were in the good equilibrium. In a banking panic, "true" solvency is an outof-equilibrium attribute, not an observable, objective reality.

That banks' solvency should be assessed with reference to hypothetical market conditions is consistent with some interpretations of the classical doctrine of lending-in-lastresort. This is for example the way Fischer (1999) interprets Bagehot's rule that the LOLR should lend "on any collateral that is marketable in the ordinary course of business when there is no panic". The requirement that lending should be made on the basis of the value of collateral in normal times can be interpreted as taking the good equilibrium as the benchmark to assess the solvency of banks. In terms of our model, the authorities must assess the value of banks'

\footnotetext{
22 This is the way lending-in-last-resort is modeled in Chang and Velasco (2000) and Goldfajn and Valdes (1999).
} 
collateral on the basis of the price that prevails in the good equilibrium, $P_{A}^{*}$. In the bad equilibrium, $P_{A}^{*}$ is a shadow price which is larger than the observed market price, $P_{C}^{*}$.

It is easy to see that this arrangement reduces the set of equilibria to the good equilibrium. The international LOLR's intervention breaks the vicious circle depicted in figure 5 by preventing bank runs from resulting in an excessive depreciation of the exchange rate. It ensures that the solvent banks remain in operation and that their balance sheets do not shrink in response to runs. For these banks, the only effect of the run is a substitution of creditorsprivate depositors are replaced by the central bank. As a result, there is no credit crunch in the "truly solvent" part of the banking sector, and the pressure on the exchange rate is reduced accordingly.

The argument can be presented more formally - in terms of the equations of the model-as follows. Let $n_{A}$ denote the number of insolvent banks in the good equilibrium. With discount-window lending, runs on the truly solvent banks no longer contribute to the credit crunch, so that in the Phillips Curve (5) variable $n$ must be replaced by $\min \left(n, n_{A}\right)$, the number of insolvent banks that are subject to runs. The equation for the linkage from bank runs to the exchange rate then becomes:

$$
S_{2}=\bar{S}-\frac{\alpha}{\beta} f\left(\min \left(n, n_{A}\right)\right)
$$

In figure 6 the locus $(C C)$ becomes horizontal to the right of point $A$, implying that the set of equilibria is reduced to the good equilibrium (see figure 7).

\section{Figure 7. Discount-Window Lending}

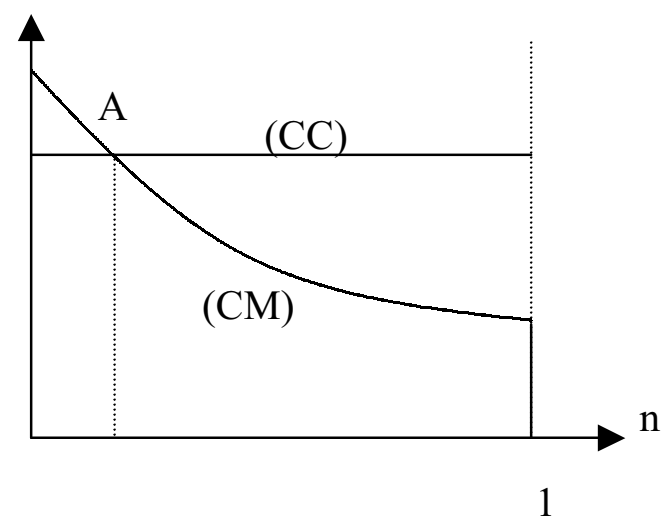

The case where the international LOLR backs a domestic guarantee on the dollar deposits can be analyzed along similar lines, although there is an interesting difference in the economic mechanism involved. The government announces that it guarantees deposits at truly 
solvent banks - where again, true solvency is assessed with reference to the good equilibrium. This breaks the vicious circle depicted in figure 5 by suppressing the linkage from the currency depreciation to bank runs. The depositors, once insured, no longer have (strict) incentives to run against the truly solvent banks. The expectation of a depreciation is no longer self-fulfilling because it does not provoke a banking collapse.

In terms of the equations of the model, the guarantee affects the relationship between the expected exchange rate and the number of bank runs, equation (4). Developments in the foreign exchange market no longer affect the truly solvent banks, so that (4) is replaced by $n=\min \left(n_{A}, N\left(S_{2}^{e}\right)\right)$. The equation for locus $(C M)$ becomes:

$$
n=\min \left(n_{A}, N\left(S_{2}\right)\right) \quad\left(C M^{\prime}\right)
$$

In figure 6 the locus $(C M)$ becomes vertical in point $\mathrm{A}$, so that again the good equilibrium is the only one (see figure 8 ).

Figure 8. Guarantee on Dollar Deposits

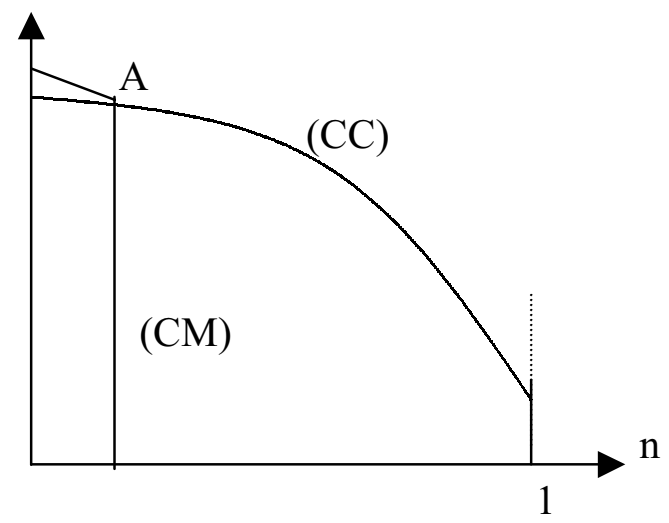

In order to make these arrangements operational the resources of the international LOLR do not need to be larger than the liquidity gap in the domestic banking sector, $D^{*}-X^{*}$. Indeed, its resources could even be smaller since the liabilities of the truly insolvent banks do not have to be covered in the event of a crisis. This does not seem unrealistically large. As documented in section 2, the IMF-supported rescue packages were of the same order of magnitude as the liquidity gap in the Asian countries that were most affected by the crisis.

In sum, we find that an international LOLR backing domestic safety nets needs much less resources than an international LOLR injecting liquidity in the market. It can operate as a limited "international banking fund" and would not necessarily need to be considerably larger than existing international financial institutions. This conclusion, however, ignores one 
important aspect of the problem, to which we now turn: agency problems between the international LOLR and the domestic authorities.

\section{B. International Agency Problems}

One question that we have not addressed so far is the articulation between the international LOLR and the domestic authorities. To which extent should the international LOLR rely on the domestic authorities to funnel the liquidity towards domestic banks? So far this question did not come up because we implicitly assumed that the international LOLR and the domestic authorities shared the same objectives. However, the involvement of two different authorities in the international lending-in-last-resort arrangement might give rise to agency problems (Tirole, 2000). We discuss in this section how agency problems might arise in our framework, as well as the measures to mitigate them.

An agency problem would arise if the domestic authorities thought that the cost of bailing out the "truly insolvent" banks could somehow be transferred to the international community. The domestic authorities would then be tempted to use the lending-in-last-resources in order to bail out the domestic banks that are insolvent in the good equilibrium, at the expense of the foreign taxpayers. As argued by Jeanne and Zettelmeyer (2001), an agency problem could arise even if the fiscal cost of the bailout is borne by the domestic taxpayer. In this case, the problem is that the domestic authorities use the bridge loans from the international community be overly generous with the domestic special interests that benefit from the bail-out, at the expense of the domestic taxpayers.

Agency problems could arise at several levels. First, the international LOLR might be unable to ensure that its resources are not misused by the domestic authorities (to bail out insolvent banks). Second, even if the international LOLR had full control of the way its resources are used-which would be the case, for example, if it lent directly to domestic banks - it might not have all the information that is required to use these resources appropriately. Ideally, the international LOLR should be able to assess the "true solvency" of banks in a crisis. This is informationally very demanding - it requires a precise knowledge of the various feedbacks between the banking system, the productive sector and the foreign exchange market, as well as the structure of banks' balance sheets. ${ }^{23}$ In a world where banking supervisory policies are determined at the national level, most of the relevant knowledge is the private information of the domestic authorities, and they would have little incentives to reveal it truthfully to the international LOLR.

${ }^{23}$ As we saw in the previous section, banks' solvency must be assessed on the basis of an appropriate shadow price for the collateral. Computing the shadow price is challenging. In general, there is no reason to presume that the appropriate shadow price is close to the pre-crisis level. In a world where crises are associated with the arrival of news about the fundamentals, the appropriate shadow price should be revised in light of the new information revealed by (or causing) the crisis. 
There are different ways to deal with this agency problem but they all seem to require a significant involvement of the international LOLR in banking supervision and safety nets. The international LOLR would have to be associated with the lending-in-last-resort decisions at the time of the crisis, and should be able to form an independent judgment on the true solvency of banks in a banking crisis. This supposes some access to the information of the banking supervisors, and some assurance that this information is reliable. Consequently, the international LOLR would probably have to take an active role in monitoring domestic banking systems, or cooperate closely with an international agency in charge of international supervision. ${ }^{24}$

How realistic is this involvement of the international LOLR in the supervision of domestic banking sectors? In spite of efforts at promoting international standards, the operation of financial safety nets and financial oversight policies remains - and will remain for the foreseeable future - squarely within the bounds of national sovereignty (Eichengreen, 1999). Nations remain jealous of their prerogatives in the regulation and supervision of their banking sectors, and there seems to be little political appetite for a globally integrated system with the IMF, the BIS or any new institution at its center. The domestic resistance to the integration of banking supervision in the euro area - which is so closely integrated in other respects - gives an idea of the difficulties that would arise at the global level. Ultimately, it is not clear that a globally integrated system of banking supervision is more realistic than a global central bank.

\section{Concluding Comments}

The main result of this paper should be to instill a solid degree of skepticism regarding the feasibility of international LOLR without sweeping institutional reforms. If the international LOLR uses its resources as an input into monetary policy, the model presented here vindicates those who claim that it must stand ready to provide virtually unbounded amounts of currency. Central banks satisfy this condition, not any existing international financial institution. The alternative is an "international banking fund" that is directly involved in the supervision of the domestic banking systems that it might be called upon to rescue - an institutional arrangement that would also require significant reforms in the international financial architecture.

An interesting by-product of the paper is to interpret the trade-off that central banks often face at the time of currency crises. A vigorous interest rate defense weakens the banking system. If banks are fragile, central banks risk triggering a bank run and may end up with both a currency crash and a bank collapse. On the other hand, letting the currency go is not a solution either, since this also weakens the banking system by decreasing the dollar value of its assets. This dilemma explains part of the debate that has arisen after the Asian crisis, between those

${ }^{24}$ The IMF has recently enhanced its monitoring of domestic banking and financial systems with, for example, the development of its Financial Sector Assessment Programs (FSAP)—see IMF (2001). 
who favored a vigorous interest rate defense and those who called for a sharp decline in interest rates.

The model presented has a number of microeconomic loose ends. The special role of banks in financial intermediation, which is invoked to justify the credit crunch term in the Phillips curve, it is not explicitly modeled. The balance sheet effects, which are so important in triggering bank runs in period 1, are neglected in period 2. Fixing these loose ends will probably lower the insight-to-algebra ratio, a price which seems to us worth paying now that we have taken a panoramic shot of the range of policy issues on which the model sheds light.

The model also glosses over several important moral hazard issues. This includes the role of a fixed exchange rate as an implicit guarantee on foreign borrowing and the effect of a LOLR on risk taking. Finally, it should be noted that if regulation prohibited open currency position by banks is effective, none of our results obtain. Then, however, we would need to take into account that firms rarely face such a regulation. If the corporate sector becomes insolvent as banks do in our model, and precipitate bank failures, most of our results stand. But there are interesting differences in the effectiveness of financial safety nets, which would be interesting to explore further. It is not so clear that the provision of liquidity to the banking sector, or government guarantees on banks' liabilities, would remove the bad equilibrium if the currency mismatch is in the corporate sector. 


\section{Data Sources}

Foreign exchange reserves: International Financial Statistics, line 1d.

Short-term debt to BIS reporting banks: BIS.

Foreign liabilities of deposit money banks: International Financial Statistics, line $26 \mathrm{c}$.

Liquidity support to financial institutions: author's computations based on Lindgren and others (1999), table 3.

IMF-supported packages (disbursements): author's computations based on different sources; this variable includes the loans by the IMF, other multilaterals and governments; it reflects the actual disbursements, which were lower than the initial commitments.

Bank closures: Lindgren and others (1999), table 7.

Total assets owned by banks: Lindgren and others (1999), box 3 .

GDP (bn U.S. dollars): International Financial Statistics, line 99b (Gross Domestic Product, national currency) divided by line rf (exchange rate). 
This appendix solves for the equilibria in the general case where banks have peso- and dollar-denominated deposits and income streams. The quantities of peso and dollar deposits at bank $j$ are denoted by $D(j)$ and $D^{*}(j)$. Bank $j$ 's peso-denominated and dollar-denominated income streams in period $t$ are denoted by $R_{t}(j)$ and $R_{t}^{*}(j)$.

Using uncovered interest parity (1) to substitute $S_{1}$ out of equation (2), the condition for bank j's solvency becomes:

$$
D^{*}(j)-\left(R_{1}^{*}(j)+\frac{R_{2}^{*}(j)}{1+i^{*}}\right)<\frac{S_{2}^{e}}{1+i^{*}}\left(\left(R_{1}(j)-D(j)\right)(1+i)+R_{2}(j)\right)
$$

The impact of the interest level on bank $j$ 's solvency depends on the sign of $R_{1}(j)-D(j)$, which reflects the maturity mismatch between assets and liabilities denominated in domestic currency. If $R_{1}(j)-D(j)<0$, that is if the bank has more short-term debt than liquid assets in domestic currency, then raising the interest rate undermines the bank's solvency. On the other hand if $R_{1}(j)-D(j)>0$ raising the interest rate enhances the bank's solvency.

In aggregate, raising the interest rate increases (reduces) the number of insolvent banks if $R_{1}(j)-D(j)<0\left(R_{1}(j)-D(j)>0\right)$ for all banks. If the sign of $R_{1}(j)-D(j)$ differs across banks, then the impact of the interest rate on the number of insolvent banks is ambiguous. We denote by $I\left(S_{2}^{e}\right)$ the interest level that minimizes the number of insolvent banks when the expected exchange rate is $S_{2}^{e}$, and by $N\left(S_{2}^{e}\right)$ the corresponding number of insolvent banks.

How does the minimum number of insolvent banks, $N\left(S_{2}^{e}\right)$, vary with the expected exchange rate? This question is easy to answer if we assume that all the banks are short in dollars, that is, if the left-hand-side of equation (A1) is positive. Then the set of solvent banks shrinks for any level of the interest rate when $S_{2}^{e}$ decreases, implying that the minimum number of insolvent banks, $N\left(S_{2}^{e}\right)$, is a decreasing function of $S_{2}^{e}$.

We define the rules of the game between the domestic central bank and the depositors as follows. First, the central bank announces how it will adjust the interest rate to the economic conditions, i.e. its policy reaction function $i\left(S_{2}^{e}\right)$. Then, depositors play the same Nash game as before, taking the central bank policy reaction function as given. Depositors still maximize their expected consumption, and the central bank minimizes its expected loss $L_{2}^{e}$. 
Because the central bank's expected loss is increasing in the number of bank runs, it optimally announces the policy rule that minimizes the number of runs, $I\left(S_{2}^{e}\right)$. Given this policy rule, the equilibrium number of runs is a decreasing function of the expected exchange rate, like before:

$$
n=N\left(S_{2}^{e}\right), \quad N^{\prime}<0 .
$$

This equation is the same as equation (4) in the text, and the characterization of the equilibria remains the same. 


\section{References}

Aghion, Philippe, Philippe Bacchetta, and Abhijit Banerjee, 2000, "Currency Crises and Monetary Policy in an Economy with Credit Constraints," mimeo, Department of Economics, Harvard University.

Bacchetta, Philippe, 2000, "Monetary Policy with Foreign Currency Debt," mimeo, Study Center Gerzensee, Bank of Switzerland.

Bordo, Michael, 1990, "The Lender of Last Resort: Alternative Views and Historical Experience," Federal Reserve Bank of Richmond Economic Review, Vol. 76, No. 1, pp. 18-29.

Burnside, Craig, Martin Eichenbaum, and Sergio Rebelo, 1998, "Prospective Deficits and the Asian Currency Crisis,” NBER Working Paper No. 6758.

— , 1999, "Hedging and Financial Fragility in Fixed Exchange Rate Regimes," mimeo, Kellogg Graduate School of Management.

Caballero, Ricardo J. and Arvind Krishnamurthy, 2000, "Dollarization of Liabilities: Underinsurance and Domestic Financial Underdevelopment," mimeo, Department of Economics, MIT.

Calomiris, Charles W., 1998, “The IMF's Imprudent Role as Lender of Last Resort," Cato Journal, Vol.17, pp. 275-95.

Capie, Forrest, 1998, “Can There Be an International Lender-of-Last-Resort?” International Finance, Vol. 1, pp. 311-325.

Céspedes, L. F., R. Chang and A. Velasco, 2000, “Balance Sheets and Exchange Rates,” NBER Working Paper No. 7840.

Chang, Roberto and Andres Velasco, 2000, "Liquidity Crises in Emerging Markets: Theory and Policy," in NBER Macroeconomics Annual 1999, ed. by Ben S. Bernanke and Julio Rotemberg (Cambridge, MA: MIT Press).

Christiano, Lawrence J., Christopher Gust, and Jorge Roldos, 2000, “Monetary Policy in a Financial Crisis," mimeo, International Monetary Fund, Washington D.C..

Diamond, D. and P. Dybvig, 1983, “Bank Runs, Deposit Insurance, and Liquidity," Journal of Political Economy, Vol. 91, pp. 401-19.

Ding, Wei, Ilker Domaç, and Giovanni Ferri, 1998, "Is There a Credit Crunch in East Asia?" World Bank Policy Research Working Paper No.1959. 
Disyatat, Piti, 2000, "Currency Crises and the Real Economy: The Role of Banks," mimeo, Department of Economics, Princeton University.

Eichengreen, Barry, 1999, Toward a New Financial Architecture (Washington: Institute for International Economics).

Fischer, Stanley, 1999, "On the Need for an International Lender of Last Resort," Journal of Economic Perspectives, Vol. 13, pp. 85-104.

Fischer, Stanley, 2000, “On the Need for an International Lender of Last Resort," Essays in International Economics, No. 220, (Princeton, NJ: International Economics Section, Princeton University).

Fratianni, Michele and John Pattison, 2001, "International Lender of Last Resort: A Concept in Search of a Meaning," mimeo, Kelley School of Business, Indiana University.

Freixas, Xavier and Jean-Charles Rochet, 1997, Microeconomics of Banking (Cambridge MA: MIT Press).

Furman, Jason and Joseph Stiglitz, 1998, "Economic Crises: Evidence and Insights from East Asia," Brookings Papers on Economic Activity, No. 2, pp. 1-114.

Garten, Jeffrey, 1998, "In This Economic Chaos, a Global Central Bank Can Help," International Herald Tribune, 25 September, pp. 8.

Gertler, Mark, Gilchrist, Simon, and Fabio M. Natalucci, 2000, "External Constraints on Monetary Policy and the Financial Accelerator," mimeo, Department of Economics, New York University.

Ghosh, Swati R. and Atish R. Ghosh, 1999, "East Asia in the Aftermath: Was There a Crunch?" IMF Working Paper 99/54 (Washington: International Monetary Fund).

Giannini, Curzio, 2000, “Pitfalls In International Crisis Lending," mimeo, Banca d'Italia, and forthcoming in Financial Crises, Contagion, and the Lender of Last Resort: a Book of Readings, ed. by Charles Goodhart and Gerhard Illing (Oxford: Oxford University Press).

Goldfajn, Ilan and Rodrigo Valdes, 1999, "Liquidity Crises and the International Financial Architecture," mimeo, Department of Economics, PUC-Rio.

Goodfriend, Marvin and Robert King, 1988, "Financial Deregulation Monetary Policy and Central Banking," in RestructuringBanking and Financial Services in America, ed. by W.Haraf and R.M. Kushmeider (Lanham, MD: American Enterprise Institute and UPA). 
Goodhart, Charles and Haizhou Huang, 2000, “A Simple Model of an International Lender of Last Resort," IMF Working Paper 00/75 (Washington: International Monetary Fund).

Humphrey, Thomas, 1975, "The Classical Concept of the Lender of Last Resort," Federal Reserve Bank of Richmond Economic Review, Vol. 61, pp. 2-9.

International Financial Institution Advisory Commission, 2000, Report of the International Financial Institution Advisory Commission, Allan H. Meltzer, Chairman, also known as the Meltzer Report (Washington DC, March).

International Monetary Fund, 2001, Report of the Managing Director to the International Monetary and Financial Committee on the IMF in the Process of Change, http://www.imf.org/external/np/omd/2001/report.htm.

Jeanne, Olivier, 2000a, “Debt Maturity and the Global Financial Architecture," CEPR Discussion Paper No. 2520.

Jeanne, Olivier, 2000b, "Foreign Currency Debt and the Global Financial Architecture," European Economic Review, Vol. 44, pp. 719-727.

Jeanne, Olivier, 2000c, "Currency Crises: A Perspective on Recent Theoretical Developments," Special Papers in International Economics, No. 20 (Princeton, NJ: International Finance Section, Department of Economics, Princeton University).

Jeanne, Olivier and Jeromin Zettelmeyer, 2001, "International Bail-outs, Moral Hazard, and Conditionality," paper prepared for the $33^{\text {rd }}$ Economic Policy Panel.

Kaminski, Graciela and Carmen Reinhart, 1999, "The Twin Crises: The Causes of Banking and Balance-of-Payments Problems," American Economic Review, Vol. 89, pp. 473-500.

Kumar, Mohan, Paul Masson, and Marcus Miller, 2000, "Global Financial Crises: Institutions and Incentives," IMF Working Paper 00/105 (Washington: International Monetary Fund).

Lindgren, Carl-Johan, Tomas J. T. Baliño, Charles Enoch, Anne-Marie Gulde, Marc Quintyn, and Leslie Teo, 1999, "Financial Sector Crisis and Restructuring: Lessons from Asia," IMF Occasional Paper No. 188 (Washington: International Monetary Fund).

Morris, Stephen and Hyun Song Shin, 1998, "Unique Equilibrium in a Model of Self-Fulfilling Currency Attacks," American Economic Review, Vol. 88. pp. 587-597.

Prati, Alessandro and Gary Schinasi, 2000, "Will the European Central Bank Be the Lender of Last Resort in EMU?," in The Euro: A Challenge and Opportunity for Financial Markets, ed. by M.Artis, A.Weber, and E.Hennessy, pp. 227-56 (New York: Routledge). 
Rogoff, Kenneth, 1999, "International Institutions for Reducing Global Financial Instability," Journal of Economic Perspectives, Vol. 13, pp. 21-42.

Rubin, Robert E., 1999, Testimony on Global Financial Architecture Before the House Committee on Banking and Financial Institutions, May 20, http://www.ustreas.gov/press/releases/pr3161.htm.

Sachs, Jeffrey, 1995, “Do We Need an International Lender of Last Resort?," Frank D Graham Lecture, Princeton University.

Schneider, Martin and Aaron Tornell, 2000, "Balance Sheet Effects, Bailout Guarantees, and Financial Crises,” NBER Working Paper No. 8060.

Thornton, Henry, 1802, An Enquiry into the Nature and Effects of the Paper Credit of Great Britain, reprint ed. 1978 (Fairfield Kelley).

Tirole, Jean, 2000, "Liquidity Provision and the International Financial System," draft of the Paolo Baffi Lecture on Money and Finance. 